ІНФОРМАЦІЙНА ВЗАЄМОДІЯ ЯК БАЗОВА ХАРАКТЕРИСТИКА ІНФОРМАЦІЙНОЇ КУЛЬТУРИ ОСОБИСТОСТІ МАЙБУТНЬОГО ФАХІВЦЯ

\title{
INFORMATION INTERACTION AS A BASIC CHARACTERISTIC OF THE INFORMATION CULTURE OF THE FUTURE SPECIALIST'S PERSONALITY
}

В умовах розвитку інформаційного суспільства відбуваються зміни в культурі. Такий ї̈ складник, як інфрормаційна культура, починає визначати специфріку всієї культури як цілого. Виникає протиріччя між усіма складниками культури, що призводить до появи різних проблем, які вимагають вирішення. Однією з таких актуальних проблем сьогодні $є$ проблема взаємодії. Щоб вивчити можливі негативні й позитивні наслідки переходу до нового типу культури, а отже, і цивілізаціі, необхідно зрозуміти механізми інформаційної взаємодії. Як методи дослідження використано діалектичний метод, діяльнісний підхід, метод аналізу й узагальнення.

Також у статmі визначено різні підходи до френомену інфрормаційної культури: інформологічний, культурологічний i фрілософрський. Із позицій цих підходів визначено розуміння френомену «інформаційна культура». Автор стверджує, що в інорормаційній культурі особистості виділяється чотири основні компоненти: когнітивний, емоційно-ціннісний, дієво-практичний, комунікативний. Детально розкрито кожен із компонентів. Доведено, що інорормаційна взаємодія $є$ ключовою характеристикою інфрормаційної культури особистості. Проаналізовано зміст категорій «взаємодія», «інфрормаційна взаємодія». Показано, що взаємодія служить основою розвитку. Наведено поняття і структуру інфрормаційної взаємодії, розглянуто їі місце і роль у системі освіти.

Проведене дослідження показало, що вивчення проблеми інфрормаційної взаємодії вимагає звернення до фрілософьської методології в плані розроблення категоріального апарату, здатного розкрити суть і специ фріку нових френоменів інформаційного суспільства. Крім того, потрібне проведення комплексного дослідження позначеної проблеми у рамках сучасного наукового знання. Показано, що необхідно продовжити наукові пошуки в контексті дослідження саме особливостей фрункціонування особистості як суб'єкта інформаційного взаємодії в інфрормаційному просторі. Це створить теоретичне підгрунтя для дослідження змісту та формування інфрормаційної культури майбутнього фрахівця.

Ключові слова: інфрормаційна культура, інорормаційна взаємодія, майбутній фрахівець, інфрормаційне суспільство, освіта, взаємодія, культура.
In the conditions of development of information society changes in culture take place. Its component as information culture begins to determine the specificity of the whole culture as a whole. There is a contradiction between all the components of the culture, leading to various problems that require solutions. One of the pressing problems today is the problem of interaction. In order to study the possible negative and positive effects of the transition to a new type of culture, and therefore civilization, it is necessary to understand the mechanisms of information interaction. Dialectical method, activity approach, method of analysis and generalization were used as research methods.

Also, the article identifies different approaches to the phenomenon of information culture: informological, cultural and philosophical. From the standpoint of these approaches the understanding of the phenomenon "information culture" is defined. The author states that in the information culture of the personality there are four main components: cognitive, emotional-value and effective-practical, communicative. Each of the components is disclosed in detail. The article proves that information interaction is a key characteristic of an individual's information culture. The content of interaction categories, information interaction is analyzed. It is shown that interaction is the basis of development. The article presents the concept and structure of information interaction, examines its place and role in the education system.

The study showed that studying the problem of information interaction requires an appeal to philosophical methodology in terms of developing a categorical apparatus capable of revealing the essence and specificity of new phenomena of the information society. In addition, a comprehensive study of the problem identified in the context of modern scientific knowledge is required. It is shown that it is necessary to continue scientific research in the context of the study of the peculiarities of the functioning of the individual as the subject of information interaction in the information space. This will create a theoretical basis for the study of the content and formation of the information culture of the future specialist.

Key words: information culture, information interaction, future specialist, information society, education, interaction, culture.
Центральноукраїнського національного технічного університету
Постановка в загальному вигляді. Аналіз сучасності виявляє наявність протиріччя між зростаючою вимогою сучасної дійсності до закладів вищої освіти з підготовки випускника, що вміє отримувати і використовувати інформацію із застосуванням комп'ютерної техніки для вирішення професійних та соціальних завдань, і неопрацьованістю педагогічних умов та технологічних механізмів розвитку готовності студентів до цієї діяльності. Це протиріччя визначило проблему, яка полягає у виявленні педагогічних умов і засобів, що забезпечують розвиток нової інфрормаційної культури особистості студентів в освітньому просторі закладу вищої освіти.

Актуальність дослідження проблеми інорормаційної культури підтверджується також тим, що, по-перше, у фрілософії, культурології, педагогіці й інших наукових галузях знання активізувалися 
пошуки відповідей на багато питань, пов'язаних із сутністю інорормаційної культури особистості. По-друге, тим, що завдяки високим темпам інорорматизації суспільства, оновленню інфрормаційних ресурсів, розвитку теорії інорорматизації, створенню інформаційного освітнього середовища, активному розвитку системи підготовки тих, що навчається, до інформаційної діяльності, з'явилися передумови для створення сучасної моделі інформаційної культури і вирішення проблеми її розвитку як цілісності.

Аналіз останніх досліджень і публікацій. Проблема розвитку інорормаційної культури тих, що навчається, у системі освіти знаходиться на перетині таких наук, як фрілософрія, культурологія, психологія, педагогіка. Даній проблемі присвячено дослідження, в яких:

а) вивчено різноманітні аспекти культури як простору становлення людини (А.І. Арнольдов, К. Беннст, О.Г. Асмолов, М. Вебер, В.М. Межуєв, Д. Садкер та ін.);

б) спираючись на сутність культурологічного підходу, сорормульовано розуміння інформаційної культури як результату рефрлексії людського досвіду (А.І. Арнольдов, М.П. Ващекін, І.І. Горлова, Г.Г. Гранатов, О.А. Гречіхін та ін.);

в) здійснено фрілософрсько-світоглядний (А.П. Суханов, В.М. Петров, Е.П. Семешок, А.Д. Урсул, І.І. Юзвішін та ін.) та психолого-педагогічний (О.О. Андрєєв, В.М. Васильєв, Я.В. Галета, Г.Г. Гранік, Р.М. Грановська, Л.П. Гурьєва, Д.Ш. Матрос та ін.) аналіз ореномену інформаційної культури;

г) розроблено концепції, що обґрунтовують соціально-культурну сутність інорорматизації (М.В. Арапов, А.І. Арнольдов, М.П. Ващекін, А.І. Ракітов та ін.);

д) досліджено методологічні й методичні аспекти проблеми фрормування і розвитку інформаційної культури (О.О. Андрєєв, В.М. Васильєв, Я.В. Галета, Г.Г. Гранік, Р.М. Грановський, Л.П. Гурьєва, Д.Ш. Матрос та ін.).

Незважаючи на це, сьогодні не склалося єдиного уявлення щодо трактування поняття «інфрормаційна культура особистості».

Мета статті. Мета роботи - показати, що інфрормаційна взаємодія є базовою характеристикою інфрормаційної культури особистості.

Виклад основного матеріалу. У суспільстві виробилися різні підходи до розуміння феномену інфрормаційної культури. Залежно від об'єкта вивчення виділяють інорормаційну культуру суспільства, інорормаційну культуру окремих категорій споживачів інорормації й інфрормаційну культуру особистості. В.Є. Лєончиков відзначає, що інфрормаційна культура виступає «у трьох іпостасях: інформаційна культура особистості, окремих груп співтовариства і суспільства у цілому» [9].
Інформаційна культура члена сучасного інформаційного суспільства може бути представлена як відносно цілісна підсистема професійної і загальної культури людини, пов'язана $з$ ними єдиними категоріями (культура мислення, поведінки, спілкування і діяльності) і що складається 3 кількох взаємопов'язаних структурних елементів.

Виходячи 3 аналізу психолого-педагогічної літератури (А.М. Атаян, В.Я. Буторін, С.М. Олєнєв, Т.А. Полякова, Е.П. Семенюк), виділимо в найбільш загальному вигляді компоненти інформаційної культури: аксіологічний компонент (прийняття на особистісному рівні гуманістичної цінності інорормаційної діяльності людини); комунікативний компонент (культура спілкування і співпраці в галузі інфрорматики й інформаційних технологій, використання можливостей телекомунікацій для міжособистісної та колективної взаємодії, моральна поведінка у сорері інформаційних відношень); інтелектуальний компонент (компетентність і вільна орієнтація у сорері інорормаційних технологій, гнучкість та адаптивність мислення); прогностичний компонент (передбачення можливих наслідків інфрормаційної діяльності, професійно-соціальна адаптація в інформаційних умовах, що постійно оновлюються); прикладний компонент (використання інорормаційно-технологічних можливостей для найбільш ефрективного вирішення профресійних завдань); правовий компонент (знання і виконання основних правових норм регулювання інформаційних стосунків, усвідомлення відповідальності за дії, що здійснюються за допомогою засобів інформатизації); ергономічний компонент (реалізація в інформаційно-професійній діяльності принципів наукової організації праці, безпеки для здоров'я, фрізіологічної комфрортності).

У категорії «інорормаційна культура» можна вкладати різний зміст: вона може трактуватися як через уміння використовувати в діяльності технології та засоби інорорматизації, так і через уміння прогнозувати та контролювати наслідки їх застосування.

Розглядаючи поняття «інфрормаційна культура особистості», ми виходимо з визначення, запропонованого Н.І. Гендіною: «Інформаційна культура особистості - один зі складників загальної культури людини, сукупність інфрормаційного світогляду і системи знань і вмінь, що забезпечують цілеспрямовану самостійну діяльність 3 оптимального задоволення індивідуальних потреб із використанням як традиційних, так і нових інорормаційних технологій. $€$ найважливішим чинником успішної профресійної і непрофесійної діяльності, а також соціальної захищеності особистості в інорормаційному суспільстві» [3]. Розвиток інфрормаційної культури особистості пов'язаний із проблемою систематичної самоосвіти впродовж усього життя через самостійну пізнавальну діяльність. 
Володіючи інфрормаційною культурою, той, що навчається, має можливість отримувати нові знання відповідно до потреб, що виникають. При цьому особа виступає не як звичайний користувач, а як суб'єкт інформаційної взаємодії, здатна до зміни самої себе і середовища.

Проведений нами аналіз онтологічних засад процесів взаємодії в природі дає змогу стверджувати, що «взаємодія» $є$ найважливішою і універсальною категорією, оскільки вона відбиває процеси дії різних об'єктів один на одного, їх взаємну зумовленість і зміну стану або взаємоперехід, а також породження одним об'єктом іншого.

О.М. Лєонтьєв, розглядаючи категорію взаємодії, підкреслює її специфріку в органічному світі, у світі живої матерії. Життя - процес особливої взаємодії особливим чином організованих тіл. Чим вище організація «тіл», тим складніше ця взаємодія [8].

Взаємодія є складною категорією, розгляд якої виходить за межі якої-небудь однієї науки, тому розкрити суть взаємодії можливо, проаналізувавши підходи різних наук (передусім гуманітарних) до розуміння цього феномену.

Зміст категорії «взаємодія» у фрілософрії пов'язаний із вивченням взаємозв'язку і взаємозалежності між взаємодіючими об'єктами. Взаємодія виступає як причина й одночасно умова виникнення тих або тих об'єктів, які вступають у певні відносини, що мають для них обопільно велике значення. За допомогою категорії взаємодії обґрунтовується принцип розвитку [6].

Філософи також пов'язують поняття взаємодії 3 поняттям структури. Так, А.Г. Чусовітін, слідуючи і розвиваючи фрілософські традиції, розглядає взаємодію як особливий вид безпосереднього або опосередкованого, зовнішнього або внутрішнього відношення, зв'язки. Властивості об'єкта можуть проявитися і бути пізнаними тільки у взаємодії 3 іншими об'єктами. Взаємодія виступає як інтегруючий чинник, за допомогою якого відбувається об'єднання частин у певний тип цілісності [14].

Для нас особливо важливий погляд фрілософрії на взаємодію людини з людиною. Однією з провідних ідей екзистенціоналізму, фрілософрсько-психологічних досліджень, фрілософської антропології $€$ уявлення про те, що особистість не можна пізнати, розглядаючи її ізольовано, поза взаємодією з іншими людьми. При цьому людина розуміється як деяке ціле, а ціле не у вигляді результату, а у вигляді процесу (процесу постійної зміни й розвитку).

Серед них важливим для нас $€$ дослідження Е.В. Ільєнкова [4, с. 387-415], у якому особистість розглядається як продукт, що складається в мережі взаємних стосунків. Учений показує, що стосунки людини 3 іншою людиною мають двосторонню спрямованість: активна дія однієї з них, спрямована на іншу, «відбивається» від неї і тим самим перетворюється на дію, спрямовану через іншу на саму себе.

Л.С. Виготський [2] зазначав, що управляти собою безпосередньо не можна, але можна опосередковано, через зовнішню, культурну точку опори. Учений говорив не просто про «виробництво» свідомості, а чітко виділяв два масштабно різних світи: «великий» світ культури і «малий» психологічний світ особистості, пов'язаних стосунками інтеріоризації/екстеріоризації. Дія культури допускає відому невизначеність поведінки, бо вона є запрошуюча сила. У квантовій механіці співвідношення невизначеностей також засноване на непорівняності за своїми масштабами мікросвіту часток і звичного нам макросвіту. Суспільні стосунки реально подані у Л.С. Виготського скоріше у формі предметно-діяльнісного змісту культури; вони виступають і як історично дані «форми спілкування», у вигляді конкретного знаково-опосередкованого спілкування дитини й дорослого в процесі їхньої спільно-розділеної діяльності, співпраці.

Звернемо увагу на взаємодію всередині особистості в контексті процесів взаємодії «Я Інший». Ю.М. Лотман, побудовувавши своє вчення про семіоссрери й культурну комунікацію, натрапив на цілу низку закономірностей і парадоксів.

Розробляючи питання й проблематику людського спілкування через призму семіотичного підходу і розглядаючи моделі комунікативних ситуацій Р. Якобсона, Ю.М. Лотман звернув увагу, що, по-перше, у культурі комунікація здійснюється мінімум по двох каналах, влаштованих по-різному. По-друге, вчений говорить про обов'язковість наявності в єдиному механізмі культури образотворчих і словесних зв'язків, які можуть розглядатися як канали передачі інорормації [10, с. 164]. Щоб виникла ця комунікація, «Я» повинне роздвоїтися, вийти із себе, щоб виникла комунікація «Я-Я». Такого роду акт описаний як у психології, так і в методології під назвою «вихід рефрлексії», і про нього можна багато говорити, піднімаючи тему комунікації . У разі комунікації всередині «Я» само роздвоєння на «я1» і «я2» має ієрархічний характер. Йдеться про те, що в акті рефлексії «Я1» переходить в «я2», що знаходиться рівнем вище. Таким чином, виникає феномен взаємодії всередині особистості (мова «я1-Я2»), який Л.С. Виготський називав «внутрішньою мовою». Тут ми маємо справу 3 якісною трансформацією особистості, підсумком якої є зміна «я1» [13, с. 6].

У цілому дослідники виділяють такі загальні ознаки взаємодії як реального явища: цілісність, одночасність існування об'єктів, двосторонність зв'язків, взаємоперехід об'єктів, взаємозумовленість змін сторін, внутрішня самоактивність суб'єктів. Оскільки освітній процес відноситься до категорії соціальних, то аналіз соціологічних 
досліджень про взаємодію індивіда 3 навколишньою дійсністю представляється нам виправданим.

Згідно з уявленнями Г. Блумера, суб'єкт, який вступає у взаємодію з оточенням, здатний не лише змінити конкретні обставини, проявляючи себе як автор і режисер того або того соціального акту, а й наново створювати самого себе в процесі його здійснення. При цьому автор уважає, що взаємодія не є простою комбінацією зовнішніх і внутрішніх чинників. Вона включає як необхідний момент і певну інтерпретацію цих чинників, що дає початок виникненню загальних сенсів [12].

Є.С. Лєгова, вивчаючи умови підвищення сумарного впливу індивіда і спільності на обопільний розвиток, називає найбільш важливим із них наявність суб'єкт-суб'єктних стосунків, які сприяють виникненню в індивідів здатності відноситися до іншого як до себе. Виділення соціологами ефекту сумарного взаємовпливу індивіда й спільності дає змогу говорити про дійсну здатність соціальної взаємодії впливати на усвідомленість, інтенсивність і продуктивність індивідуального і групового розвитку [7].

Нами виявлено значущі для нашого дослідження ідеї: пізнання людиною самої себе відбувається в актах взаємодії; взаємодія є механізмом самовдосконалення й саморозвитку.

Отже, взаємодія є об'єктивним і універсальним процесом, яким охоплені всі фрорми буття і фрорми їх віддзеркалення. При цьому кожна форма руху матерії має у своїй основі певні типи взаємодії структурних елементів. Відповідно до досягнень сучасного природознавства, фрілософрія вважає, що кожній якісно певній системі властивий особливий тип взаємодії і будь-яка взаємодія пов'язана з матеріальними полями і супроводжується перенесенням матерії, руху і інфрормації. Рух матерії в усіх його фрормах, видах і взаємоперетвореннях нерозривно пов'язаний із взаємодією елементів. При цьому кожному рівню розвитку матерії відповідає свій тип взаємодій.

Взаємодія в природі завжди, в усіх своїх проявах є обміном. Обмін - це універсальна категорія, яка використовується в усіх без винятку природничонаукових дисциплінах для опису процесів взаємодії. Фізичні, хімічні, біологічні, психічні процеси - на усіх рівнях системної організації матерії взаємодія супроводжується процесами передачі деякої субстанції від одного об'єкта до іншого. Власне кажучи, як такої «взаємодії взагалі» не існує, це не конкретна фрізична реальність. «Взаємодія» $€$ абстрактним узагальнюючим поняттям для різних форм взаємовпливу і взаємновіддзеркалення об'єктів матеріального світу. Взаємодія це процес обміну, що відбувається між матеріальними об'єктами і виявляється у передачі від одного об'єкта до іншого деякої фрізичної суті - носія взаємодії.
Дослідження існуючих у науці концепцій взаємодії показують, що категорії «інорормація» і «взаємодія» мають усе більш тісний зв'язок. Уже з'являються нові міждисциплінарні наукові напрями, що досліджують інформаційні процеси як основу взаємодій у природі. У соціальній фрілоcoфpiї так само зароджується розуміння фрундаментальної ролі інформаційної взаємодії в суспільстві. Ця проблематика активно досліджується в соціальній інформатиці, інфрормології, теоріях інформаційного суспільства. Ба більше, починають розвиватися теорії, що розглядають інформаційні процеси як основу соціальності. Серед таких теорій особливо слід відзначити теорію інформаційної взаємодії В.3. Когана, в якій він розглядає інфрормаційну взаємодію як суб'єктно-об'єктне відношення індивідів у суспільстві і визначає його як взаємодію людей у процесі виробництва, перетворення, передачі і споживання інорормації, а так само його концепції тезауруса, інфропотока й інфооронда. На нашу думку, науковий пошук у проблемному полі категорій «взаємодія», «обмін» і «інорормація» є продуктивним і дає змогу виявити основи для інтерпретації інформаційної взаємодії.

У широкому сенсі інфрормаційна взаємодія - процес обміну будь-якими видами інорормації, який тривалий час існує в людському суспільстві. Він здобуває нові форми і у міру розвитку людства стає все більш інтенсифрікованим. Таку взаємодію можна назвати інтеграційною. У вузькому сенсі під інформаційною взаємодією часто розуміють комп'ютерну інорормаційну взаємодію, що реалізовується через інорормаційні системи і інфрормаційні технології. Така взаємодія $є$ інорормаційною. Інорормаційна взаємодія також існує в різних системах: організаційних, технологічних, комп'ютерних, технічних, обчислювальних. Така взаємодія є системною. Інформаційні взаємодії відбуваються в інфрормаційному полі і в мережевих системах. Інфрормаційні взаємодії можуть бути локальними і відбуватися між частинами систем. Інформаційні взаємодії можуть бути системними і відбуватися між системами. Інформаційні взаємодії слід відрізняти від інформаційних дій або інформування [11; 15]. Інформування означає пасивну передачу інфрормації. Інорормаційна дія $€$ одностороннім процесом. Інорормаційна взаємодія двох- або багатосторонній процес. Інформаційним взаємодіям можуть відповідати деякі інформаційні стосунки. Інформаційні взаємодії можуть супроводжуватися інфрормаційною відповідністю між об'єктами взаємодії або його відсутністю.

Виходячи із загального розуміння інформаційної взаємодії як стосунків, в які вступають учасники інфопроцесу [5, с. 6-7], можна дати таке його визначення: соціальна взаємодія - це стосунки, в які вступають учасники інфрормаційного процесу в інфрормаційній реальності. 
В умовах становлення інфрормаційного суспільства інорормаційна комп'ютеризована взаємодія стає основою сучасної освіти. Про це свідчать нестримно зростаючі показники використання IKT в освіті [1].

Висновки. Таким чином, розвиток інформаційної культури особистості студента можна розглядати як розвиток здатності й потреби майбутнього фрахівця до саморозвитку і самовдосконалення шляхом свідомого й активного привласнення нового соціального досвіду в частині використання інорормаційних технологій для отримання нових знань. В основі розвитку інорормаційної культури особи лежить інфрормаційна взаємодія.

Останніми роками приділяється особлива увага розвитку інфрормаційної культури в контексті вищої освіти. Розвиток інформаційної культури майбутнього фрахівця припускає не лише розвиток у нього здібності орієнтуватися в новому інсрормаційному просторі та вміння використовувати отримані знання в навчальній і професійній діяльності, а й безперервний розвиток і саморозвиток професіонала впродовж усієї його багаторічної діяльності.

\section{БІБЛІОГРАФІЧНИЙ СПИСОК:}

1. Абдрахманова Г.И., Ковалева Г.Г. Использование информационных и коммуникационных технологий в образовании. Статистический обзор. Вопросы образования. 2010. № 3. С. 145-161.

2. Выготский Л.С. Проблемы развития психики / Собрание починений : в 6 т. Москва : Педагогика, 1983. 368 с.
3. Формирование информационной культуры личности в библиотеках и образовательных учреждениях I Н.И. Гендина и др. Москва: Школьная б-ка, 2002. 337 с.

4. Ильенков Э.В. Философия и культура. Москва : Изд-во политической литературы, 1991. 464 с.

5. Коган В.3. Теория информационного взаимодействия: Философрско-социологические очерки. Новосибирск : Новосиб. ун-т, 1991. 316 с.

6. Курбанов Р.О. Категория взаимодействия в фрилософии и научном познании : автореф. дис. ... д-ра фрилос. наук. Баку, 1989. 40 с.

7. Легова Е.С. Гегель об истоках злой воли. Вопросы фрилософии. 1996. № 11. С. 32-42.

8. Леонтьев А.А. Педагогическое общение. Москва : Знание, 1979. 509 с.

9. Леончиков В.Е. Информационная культура личности: поиски методологи. Информационное общество: культурологические проблемы : материалы междунар. науч. конфр., г. Краснодар, Новороссийск, 17-19 сентября 1997 г. Краснодар, 1997. С. 91-93.

10. Лотман Ю.М. Семиоссрера. Санкт-Петербург : Искусство, 2000. 704 с.

11. Охотников А.Л. Информационный морфизм в информационном поле. Перспективы науки и образования. 2017. № 4(28). С. 7-11.

12. Современная американская социология / под ред. В.И. Добренькова. Москва : МГУ, 1994. 294 с.

13. Ухтомский А.А. Избранные труды. Ленинград : Наука, 1978. 370 с.

14. Чусовитин А.Г. Концепция взаимодействия : автореф. дисс. ... д-ра фрилософ. Наук : 09.00.01. Новосибирск, 1991. 52 с.

15. Tsvetkov V.Ya. Information interaction. European Researcher. Series. A. 2013. Vol. 62. №. 11-12. P. 2573-2577. 